Arc. Com. Health • Juni 2018

ISSN: 2527-3620

\title{
FAKTOR YANG BERHUBUNGAN DENGAN KEJADIAN GIZI LEBIH PADA SISWA TAMAN KANAK-KANAK DI KECAMATAN DENPASAR BARAT
}

\author{
I Gde Made Swastika Dharmadi*, Ni Wayan Arya Utami \\ Program Studi Sarjana Kesehatan Masyarakat Fakultas Kedokteran Universitas Udayana \\ *email: swastikadharmadi182@gmail.com
}

\begin{abstract}
ABSTRAK
Kasus kelebihan berat badan merupakan salah satu masalah gizi terhadap masyarakat untuk semua umur terutama masyarakat di negara maju. Menurut beberapa penelitian, peningkatan jumlah kasus kelebihan gizi cenderung dialami oleh anak-anak prasekolah dan mereka berisiko menjadi orang dewasa yang kelebihan berat badan dan obesitas. Prevalensi anak yang kelebihan berat badan usia 3-6 tahun yang semakin meningkat dari tahun ke tahun. Tujuan dari penelitian ini adalah untuk mengetahui representasi dan faktor-faktor yang berhubungan dengan kasus anak prasekolah yang kelebihan berat badan. Penelitian ini menggunakan analisis cross-sectional dengan jumlah sampel 75 anak yang merupakan siswa di TK Denpasar barat; yang diambil dalam cluster sampling untuk menentukan sampel TK dan simple random sampling untuk menentukan ukuran sampel TK. Data dikumpulkan dengan metode wawancara dan dianalisis secara univariat dan bivariat. Hasil penelitian menunjukkan bahwa representasi kasus anak TK kelebihan berat badan di TK Denpasar barat adalah 20\%. Faktor nilai yang mempengaruhi kasus anak TK kelebihan berat badan adalah konsumsi makanan cepat saji $(\mathrm{PR}=2,98$; $\mathrm{p}$ $<0,0131)$, aktivitas fisik ringan ( $P R=4,17, P=0,0008)$, pemberian ASI eksklusif $(P R=0,34 ; p=0,0184)$, status gizi ibu $(P R=4,61 ; p=0,0013)$,, status kerja ibu $(P R=2,68 ; p=0,0356)$. Kolaborasi orang tua, partisipasi sekolah, dan lingkungan banjar diperlukan dalam pencegahan kelebihan berat badan sehingga mereka dapat berperan aktif dalam mencegah anak sejak dini. Selanjutnya, jika peneliti ingin melakukan yang serupa dengan penelitian ini, diharapkan bisa lebih baik dalam mengukur aktivitas fisik dan asupan gizi responden.
\end{abstract}

Kata Kunci : Kelebihan Berat Badan, Taman Kanak-Kanak, ASI, Status Gizi Ibu, Konsumsi Makanan Cepat Saji

\begin{abstract}
Overweight case is one of nutritional problems toward society for all ages especially society in developed country. According to several researches, increasing numbers of overnutrient case tend to be experienced by preschool children and they risk becoming overweight and obese adults. Prevalence of overweight children ages 3-6 years old which is more increasing year by year. The aim of this research is to know the representation and the factors which relate with overweight preschool children case. This research used cross-sectional analysis with 75 children as sample size who are students in west Denpasar Kindergarten; which are took in cluster sampling for determining kindergarten sample and simple random sampling for determining kindergarten sample size. The data is collected by interview method and is analysed in univariate and bivariate. The result showed that representation of overweight kindergarten children case in west Denpasar kindergarten is $20 \%$. Value factors which influence the overweight kindergarten children case were fast food consumption $(\mathrm{PR}=2,98 ; \mathrm{p}<0,0131)$, light physical activities ( $P R=4,17, \mathrm{P}=0,0008)$, exclusive breastfeeding ( $\mathrm{PR}=0.34 ; \mathrm{p}=0,0184)$, mother's nutritional status $(\mathrm{PR}=4,61 ; \mathrm{p}=0,0013)$, , mother's working status ( $\mathrm{PR}=2,68 ; \mathrm{p}=0,0356)$. Collaboration of parents, school participation, and banjar environment are needed in prevention of overweight so that they can play active role in preventing children since early stage. Furthermore, if the researcher wants to do similar with this research, is expected could be better in measuring physical activities and respondents' nutrient intake.
\end{abstract}

Keywords : Overweight, Kindergarten, Exclusive Breastfeeding, Mother's Nutritional Status, Fast Food Consumption

\section{PENDAHULUAN}

Permasalahan gizi lebih dapat terjadi pada semua tahap usia mulai dari anak anak, remaja, hingga dewasa.Kejadian gizi lebih pada kelompok usia dewasa lebih tinggi dibanding pada kelompok anakanak, namun pada beberapa negara telah terlihat peningkatan kejadian gizi lebih yang sangat cepat terjadi pada kelompok anak - anak dibandingkan kelompok usia dewasa (Popkin et al, 2006).

Secara global, pada tahun 2010 diperkirakan 43 juta anak prasekolah mengalami gizi lebih yang meningkat sebesar 60\% sejak tahun 1990. Sebesar 17,7 juta anak usia prasekolah di Asia 
mengalami obesitas pada tahun 2010 yang meningkat sebesar 53\% sejak tahun 1990 (de Onis, 2010).

Berdasarkan data Riset Kesehatan Dasar (Riskesdas), prevalensi nasional anak yang mengalami obesitas mengalami peningkatan yaitu tahun 2007 sebesar 4,3\%, kemudian meningkat $5,8 \%$ pada tahun 2010 dan menjadi 8,8\% pada tahun 2013. Di provinsi Bali prevalensi obesitas pada anak melebihi prevalensi nasional yaitu sebesar $4,7 \%$. Denpasar memiliki prevalensi tertinggi pada saat itu dibanding kabupaten lain, yaitu sebesar 8,6\%.

Terjadi peningkatan pada hasil riset kesehatan dasar daerah pada tahun 2013 yaitu prevalensi gizi lebih pada balita sebesar 5,5\%. Denpasar masih menduduki peringkat 5 besar kabupaten di Bali dengan prevalensi balita dengan gizi lebih sebesar $7,6 \%$.

Melihat prevalensi gizi lebih pada anak yang terus meningkat dari tahun ke tahun maka penulis tertarik untuk meneliti gambaran dan faktor yang berhubungan dengan kejadian gizi lebih pada siswa taman kanak - kanak. Penelitian dilakukan di Kecamatan Denpasar Barat karena jumlah Taman Kanak - Kanak di kecamatan tersebut paling banyak dibandingkan kecamatan lain di Kota Denpasar.

\section{HASIL}

\section{Gambaran Lokasi Penelitian}

Tabel 1 Daftar Nama Taman Kanak - Kanak

\section{METODE}

Jenis penelitian ini yaitu observasional analitik dengan rancangan cross-sectional study.Penelitian ini dilakukan pada siswa di 9 Taman Kanak - Kanak di Kecamatan Denpasar Barat selama bulanMaret - April 2016.Populasi penelitian ini yaitu siswa Taman KanakKanak yang mengalami gizi lebih di Kecamatan Denpasar Baratselama kurun waktu pengumpulan data.

Besar sampel minimal dalam penelitian ini yaitu 75 siswa Taman Kanak - Kanak. Pengambilan sampel di tiap Taman Kanak - Kanak dilakukan secara proporsional dan dengan teknik sampling berupa cluster sampling. Untuk menentukan sampel siswa Taman Kanak - Kanak digunakan teknik simple random sampling.

Data yang dikumpulkan merupakan jenis data primer. Data selanjutnya dianalisis dengan secara univariabel, dan bivariabel. Analisis bivariabel menggunakanuji Chi Square untuk variable bebas dengan dua kategori dan uji regresi poisson untuk variabel bebas lebih dari dua kategori. Ukuran asosiasi yang digunakan yaitu prevalence ratio (PR) dengan derajat kemaknaan $\alpha=0,05$.

\begin{tabular}{lcc}
\hline \multicolumn{1}{c}{ Nama Taman Kanak - kanak } & frekuensi & Persentase (\%) \\
\hline Alit Kirana & 12 & 16,00 \\
Bakti 2 & 7 & 9,33 \\
Harapan Mulia & 12 & 16,00
\end{tabular}


Arc. Com. Health Juni 2018

ISSN: 2527-3620

Kumara Santhi

Kumara Dharma Kerti

Kuncup Mekar

Rare Muchtary

Widya Kusuma Sari

Penelitian ini dilakukan di Kecamatan Denpasar Barat dimana wilayah ini memiliki akses yang cukup untuk memperoleh makanan cepat saji karena terdapat puluhan restoran cepat saji yang menyediakan menu dengan kandungan lemak tinggi seperti fried chicken, warung modern yang menyediakan menu instan di wilayah kecamatan Denpasar Barat. Secara keseluruhan di Kota Denpasar terdapat total 293 Taman Kanak - kanak. Terdapat 81 Taman kanak - kanak di Kecamatan Denpasar Barat, Kecamatan Denpasar Utara terdapat 80 Taman Kanak - Kanak, Kecamatan Denpasar Timur terdapat 61 Taman Kanak - Kanak, Kecamatan Denpasar Selatan terdapat 71 Taman Kanak - Kanak.

Penelitian ini dilakukan di 9 Taman Kanak - Kanak yang terdapat pada Kecamatan Denpasar Barat. Taman Kanak - Kanak tersebut adalah TK Alit Kirana, TK Bakti 2, TK Harapan Mulia, TK Kumara Santhi, TK Kumara Dharma Kerti, TK Kuncup Mekar, TK Rare Muchtary, TK Widya Kumara, dan TK Widya Kusuma Sari.

Berdasarkan analisis dalam penelitian ini, Hasil penelitian ini menunjukkan bahwa prealensi gizi lebih sebesar 20\%. Setiap responden diwawancarai dengan menggunakan kuesioner terstruktur untuk mendapatkan informasi mengenai karakteristik responden dan karakteristik ibu responden.

Karakteristik responden terdiri dari status gizi, jenis kelamin, riwayat pemberian ASI ekslusif, pola konsumsi fast food, pola konsumsi makanan kaleng, pola konsumsi soft drink dan aktivitas fisik anak. Karakteristik ibu responden terdiri dari status gizi, pendidikan ibu, status bekerja dan pendapatan keluarga.

\section{Faktor yang berhubungan dengan Kejadian Gizi Lebih}

Setelah masing - masing variabel dianalisis secara univariat selanjutnya variabel dianalisis secara bivariat. Pada penelitian ini ditampilkan tabel dari hasil analisis variabel secara univariat. Adapun tabelnya sebagai berikut. 
Tabel 2. Faktor yang berhubungan dengan Kejadian Gizi Lebih

\begin{tabular}{|c|c|c|c|c|c|c|c|}
\hline \multirow[t]{3}{*}{ Variabel } & \multicolumn{4}{|c|}{ Gizi Lebih } & \multirow[t]{3}{*}{ PR } & \multirow[t]{3}{*}{$95 \%$ CI } & \multirow[t]{3}{*}{$p$-value } \\
\hline & \multicolumn{2}{|c|}{ Ya } & \multicolumn{2}{|c|}{ Tidak } & & & \\
\hline & $\mathbf{n}$ & $\%$ & $\mathbf{N}$ & $\%$ & & & \\
\hline \multicolumn{8}{|l|}{ Jenis Kelamin } \\
\hline Perempuan & 7 & 46,67 & 24 & 40,00 & ref & & \\
\hline Laki-laki & 8 & 53,33 & 36 & 60,00 & 0,80 & $0,32-1,98$ & 0,6391 \\
\hline \multicolumn{8}{|l|}{ Riwayat ASI } \\
\hline Tidak Eksklusif & 9 & 60,00 & 16 & 27,59 & Ref & & \\
\hline Eksklusif & 6 & 40,00 & 42 & 72,41 & 0,34 & $0,13-0,86$ & 0,0184 \\
\hline \multicolumn{8}{|l|}{ Status Gizi Ibu } \\
\hline Normal & 4 & 26,67 & 43 & 71,67 & ref & & \\
\hline Gizi Lebih & 11 & 73,33 & 17 & 28,33 & 4,61 & $1,62-13,11$ & 0,0013 \\
\hline \multicolumn{8}{|l|}{ Pendidikan Ibu } \\
\hline Rendah & 4 & 26,67 & 11 & 18,33 & ref & & \\
\hline Tinggi & 11 & 73,33 & 49 & 81,67 & 0,68 & $0,25-1,85$ & 0,4705 \\
\hline \multicolumn{8}{|l|}{ Pendapatan Kelurga } \\
\hline$\leq 5 \mathrm{Juta}$ & 9 & 60,00 & 38 & 63,33 & ref & & \\
\hline$>5$ Juta & 6 & 40,00 & 21 & 36,67 & 1,12 & $0,45-2,81$ & 0,8113 \\
\hline \multicolumn{8}{|l|}{ Status Ibu Bekerja } \\
\hline Tidak Bekerja & 5 & 33,33 & 38 & 63,33 & ref & & \\
\hline Bekerja & 10 & 66,67 & 22 & 36,67 & 2,68 & $1,01-7,09$ & 0,0356 \\
\hline \multicolumn{8}{|l|}{ Konsumsi Fast Food } \\
\hline Jarang & 8 & 53,33 & 50 & 83,33 & ref & & \\
\hline Sering & 7 & 46,67 & 10 & 16,67 & 2,98 & $1,26-7,04$ & 0,0131 \\
\hline \multicolumn{8}{|l|}{ Konsumsi Makanan } \\
\hline Kaleng & 15 & 100 & 60 & 100 & ref & & \\
\hline Jarang & 0 & 0 & 0 & 0 & 0 & 0 & 0 \\
\hline \multicolumn{8}{|l|}{ Sering } \\
\hline \multicolumn{8}{|l|}{ Konsumsi Soft Drink } \\
\hline Jarang & 14 & 93,33 & 57 & 95,00 & ref & & \\
\hline Sering & 1 & 6,67 & 3 & 5,00 & 1,26 & $0,21-7,37$ & 0,7972 \\
\hline \multicolumn{8}{|l|}{ Aktivitas Fisik } \\
\hline Sedang & 4 & 53,33 & 10 & 90,00 & ref & & \\
\hline Ringan & 7 & 46,67 & 6 & 10,00 & 4,17 & $1,84-9,47$ & 0,0008 \\
\hline
\end{tabular}

Berdasarkan jenis kelamin, pada anak yang mengalami gizi lebih, persentase anak perempuan yaitu sebesar $46,67 \%$, sedangkan pada yang tidak gizi lebih, persentase anak yang berjenis kelamin perempuan yaitu sebesar $40 \%$. Dilihat dari nilai $\mathrm{PR}=0,80$ hal ini berarti anak dengan jenis kelamin laki-laki memiliki peluang sebesar $20 \%$ lebih rendah untuk memiliki status gizi lebih 
dibandingkan anak denganjenis kelamin perempuan. Secara statistik jika dilihat dari $p=0,6391$ hal ini berarti tidak ada hubungan yang bermakna antara jenis kelamin dengan status gizi anak.

Untuk riwayat pemberian ASI eksklusif, pada anak yang mengalami gizi lebih, persentase anak yang mendapat ASI ekslusif sebesar 40\%, sedangkan pada yang tidak mengalami gizi lebih yang mendapatkan ASI ekslusif sebesar 72,41\%. Dilihat dari nilai $\mathrm{PR}=0,34$ hal ini berarti anak dengan riwayat pemberian ASI eksklusif memiliki peluang sebesar $66 \%$ lebih kecil untuk memiliki status gizi lebih dibandingkan dengan anak dengan riwayat tidak diberikan ASI eksklusif. Secara statistik jika dilihat dari $p=0,0184$ hal ini berarti ada hubungan yang bermakna antara riwayat pemberian ASI eksklusif dengan status gizi anak.

Selain itu dilihat dari status gizi Ibu, responden dengan status gizi lebih yang yang memiliki Ibu dengan status gizi lebih sebesar $73,33 \%$ dan responden dengan status gizi normal yang memiliki Ibu dengan status gizi lebih presentasenya sebesar 28,33\%. Dilihat dari nilai $P R=4,61$ hal ini berarti anak yang memiliki Ibu dengan status gizi lebih memiliki peluang 4,61 kali lebih besar untuk memiliki status gizi lebih dibandingkan dengan anak dengan Ibu yang memiliki status gizi normal. Secara statistik jika dilihat dari $\mathrm{p}=0,0013$ hal ini berarti ada hubungan yang bermakna antara status gizi Ibu dengan status gizi anak.

Dilihat dari status pendidikan ibu, pada responden dengan status gizi lebih yang memiliki ibu dengan status
Vol. 5 No. $1: 77$ - 84

pendidikan tinggi sebesar 73,33\%. Sedangkan, pada responden yang tidak mengalami gizi lebih yang memiliki ibu dengan status pendidikan tinggi sebesar $81,67 \%$. Dilihat dari nilai $P R=0,68$ hal ini berarti anak yang memiliki Ibu dengan tingkat pendidikan tinggi memiliki peluang 32\% lebih kecil untuk memiliki status gizi lebih dibandingkan dengan anak yang memiliki ibu dengan tingkat pendidikan rendah. Secara statistik jika dilihat dari $p=0,4705$ hal ini berarti tidak ada hubungan yang bermakna antara tingkat pendidikan Ibu dengan status gizi anak.

Selain itu dilihat dari pendapatan keluarga, pada responden dengan status gizi lebih yang memiliki pendapatan keluarga lebih dari 5 juta sebesar $40 \%$, dan pada responden yang tidak mengalami gizi lebih yang memiliki pendapatan keluarga lebih dari 5 juta sebesar 36,67\%. Dilihat dari nilai $\mathrm{PR}=1,12$ hal ini menunjukkan bahwa anak dengan pendapatan keluarga kurang dari 5 juta rupiah memiliki peluang 1,12 kali lebih besar untuk memiliki status gizi lebih dibandingkan dengan anak dengan pendapatan keluarga lebih dari 5 juta rupiah. Namun jika dilihat secara statistik dari nilai $\mathrm{p}=0,8113$ artinya tidak ada hubungan yang bermakna antara pendapatan keluarga dengan status gizi pada anak.

Jika dilihat dari status pekerjaan ibu, pada responden yang mengalami gizi lebih presentase yang ibunya bekerja sebesar 66,67\%. Sedangkan, pada responden yang tidak mengalami gizi lebih presentase yang ibunya bekerja sebesar 36,67\%. Dilihat dari nilai $P R=2,68$ 
hal ini berarti anak yang memiliki Ibu bekerja memiliki peluang 2,68 kali lebih besar untuk memiliki status gizi lebih dibandingkan dengan anak yang memiliki Ibu tidak bekerja. Hasil ini juga bermakna secara statistik dengan nilai $\mathrm{p}=0,0356$.

Jika dilihat dari konsumsi fast food sebagian besar anak jarang mengkonsumsi fastfood baik anak dengan status gizi normal maupun anak dengan status gizi lebihPada responden yang mengalami gizi lebih presentase anak yang sering mengonsumsi fast food sebesar $46,67 \%$. Pada responden yang tidak mengalami gizi lebih presentase anak yang sering mengonsumsi fast food sebesar $16,67 \%$. Dilihat dari nilai $P R=2,98$ hal ini berarti anak yang sering mengkonsumsi fas tfood memiliki peluang 2,98 kali lebih besar untuk memiliki status gizi lebih dibandingkan dengan anak yang jarang mengkonsumsi fast food. Hasil ini juga bermakna secara statistik dilihat dari nilai $\mathrm{p}=0,0131$.

Dilihat dari konsumsi makanan kaleng seluruh responden baik itu anak dengan status gizi normal maupun anak dengan status gizi lebih memiliki presentase $100 \%$ jarang mengkonsumsi makanan kaleng.

Selain konsumsi fast food dan makanan kaleng dilihat juga variable konsumsi soft drink. Responden yang mengalami gizi lebih memiliki presentase anak yang sering mengonsumsi soft drink sebesar $6,67 \%$, sedangkan pada responden yang tidak gizi lebih memiliki presentase anak yang sering mengonsumsi soft drink sebesar 5\% . Dilihat dari nilai PR =1,26 hal ini berarti anak yang sering mengkonsumsi soft drink memiliki peluang 1,26 kali lebih besar untuk memiliki status gizi lebih dibandingkan dengan anak yang jarang mengonsumsi soft drink. Akan tetapi hasil ini tidak bermakna jika dilihat secara statistik $\mathrm{p}=0,7972$.

Berdasarkan analisis aktivitas fisik, diperoleh bahwa pada anak yang mengalami gizi lebih, persentase anak yang memiliki aktivitas fisik ringan yaitu sebesar 46,67\%, sedangkan pada yang tidak mengalami gizi lebih, persentase anak yang memiliki aktivitas fisik ringan yaitu hanya sebesar 10\%. Hasil analisis menunjukkan bahwa anak dengan aktivitas fisik ringan meningkatkan peluang untuk mengalami gizi lebih 4,17 kali dibandingkan dengan anak dengan aktivitas fisik sedang dan hubungan tersebut bermakna secara statistik $\mathrm{p}=0,0008$.

\section{DISKUSI}

Berdasarkan hasil penelitian maka dapat dilihat ada hubungan riwayat pemberian ASI ekslusif mengandung leptin yang merupakan hormon pengatur natsu makan/ asupan makanan dan metabolisme energi sehingga pada anak yang memiliki riwayat ASI ekslusif akan memiliki nafsu makan yang terkontrol dan metabolisme energi yang baik pada fase umur selanjutnya. Status gizi lebih ibu juga memiliki hubungan dengan status gizi lebih anak. Hal ini berkaitan dengan pemilihan asupan makanan dan kebiasan makanan yang dikonsumsi oleh orang tua di dalam keluarga. Pemilihan pola konsumsi makanan tersebut tentunya memiliki pengaruh secara tidak langsung 
Vol. 5 No. $1: 77$ - 84

terhadap makanan yang dikonsumsi oleh anaknya.

\section{SIMPULAN}

Proporsi anak yang memiliki gizi lebih yaitu sebesar 20\%. Faktor yang mempegaruhi kejadian gizi lebih pada anak yaitu riwayat asi eksklusif $(\mathrm{PR}=0,34$; 95\%CI=0,13-0,86; $\mathrm{p}=0,0184)$, status gizi ibu ( $\mathrm{PR}=4,61 ; \quad 95 \% \mathrm{CI}=1,62-13,11 ; \quad \mathrm{p}=0,0013)$ ， status ibu bekerja $(\mathrm{PR}=2,68 ; 95 \% \mathrm{CI}=1,01$ $7,09 ; \quad \mathrm{p}=0,0356)$, konsumsi fast food $(\mathrm{PR}=2,98 ; 95 \% \mathrm{CI}=1,26-7,04 ; \mathrm{p}=0,0131)$ dan aktivitas fisik ringan $\quad(\mathrm{PR}=4,17$; $95 \% \mathrm{CI}=1,84-9,47 ; \mathrm{p}=0,0008)$.

\section{DAFTAR PUSTAKA}

Anggraeni, A.C. 2012. "Asuhan Gizi;

Nutritional Care Proccess".

Yogyakarta: Graha Ilmu.

Badan Penelitian dan Pengembangan

Kementrian Kesehatan RI. 2007.

“Riset Kesehatan Dasar 2007". Jakarta: Kementrian Kesehatan RI.

Badan Penelitian dan Pengembangan

Kementrian Kesehatan RI. 2013.

“Riset Kesehatan Dasar 2013". Jakarta: Kementrian Kesehatan RI.

California Center for Public Health Advocacy (CСPHA). 2015. "Sugary Drinks : A Big Problem for Little Kids". Tersedia pada : http://www.first5la.org. Diakses tanggal 01 Juni 2016

De Onis M, Blossner M, Borghi E. 2010. WHO: "Global prevalence and trends of overweight and obesity among preschool children". Am J Clin Nutr. 2010;92:1257-64.

Dewi, AK. 2009. "Pola Makan dan Aktivitas Fisik pada Anak Sekolah
Dasar yang Menderita Gizi Lebih di Sekolah Dasar Katolik (SDK) Soverdi Tuban, Kecamatan Kuta, Badung, Bali". Skripsi. Denpasar: Universitas Udayana.

Dinas Kesehatan Provinsi Bali. 2015. "Profil Kesehatan Provinsi Bali Tahun 2014". Denpasar: Dinas Kesehatan Provinsi Bali.

Febrianto, Irwan Dwi. 2012. “Hubungan Tingkat Penghasilan, Tingkat Pendidikan, dan Tingkat Pengetahuan Orangtua tentang Makanan Bergizi dengan Status Gizi Siswa TK Islam Zahrotul Ulum Karangampel Indramayu." Skripsi. Yogyakarta: Universitas Negeri Yogyakarta.

Hapisah. 2015. "Hubungan riwayat asi eksklusif dengan kejadian obesitas pada anak usia prasekolah (4-6 tahun) di taman kanak-kanak wilayah kecamatan banjarbaru utara tahun 2014". Caring. Vol.1, No.2. Maret 2015.

Institue of Medicine. 2005. "Dietary Reference Intake for Energy, Carbohydrate, FIber, Fat, Fatty Acids, Cholesterol, Protein, and Amino Acids". A Report of The Panel on Macronutrients, Subcommittees on Upper Reference Levels of Nutrients and Interpretation and Uses of Dietary Reference Intakes and The Standing Committee on The Scientific Evaluation of Dietary Reference Intakes. Washington, DC: National Academies Press.

Keputusan Menteri Kesehatan. 2010.

"Standar Antropometri Penilaian 
Status Gizi”. Jakarta: Direktorat Bina

Gizi dan Kesehatan Ibu dan Anak.

Muliani, Gusti Ayu Kadek Ary.

"Pengaruh Pengetahuan dan Sikap tentang Obesitas serta Perilaku Konsumsi Fast food dan soft drink terhadap Kejadian Obesitas pada Anak Sekolah di SD Santo Yoseph Denpasar tahun 2014". Skripsi. Denpasar: Universitas Udayana.

Nurdin, NW. 2012. "Hubungan Status Gizi Orang Tua, Asupan Makanan, Durasi Menonton TV serta Bermain Games dan Faktor Lain dengan Status Gizi (Kegemukan) pada Siswa TK Islam Al-Azhar 03 Kota Cirebon Tahun 2012". Skripsi. Depok: Universitas Indonesia.

Putri, pramita Ariawati. 2013. “Perbedaan Asupan Energi, Lemak, Serat, dan Aktivitas Fisik pada Anak Obesitas dan Non Obesitas 3-5 tahun." Skripsi. Semarang: Universitas Diponegoro.

Sartika, RAD. 2011. “Faktor Risiko Obesitas pada anak 5-15 tahun di Indonesia". Makara Kesehatan. Vol 15 No 1 Juni 2011 37- 43. 